\title{
Generating and Allocating Internal Revenue for Public Secondary School Administration in Cross River State
}

\author{
Comfort Omori Nyeh \\ Department of Educational Management, Faculty of Education, \\ University of Port Harcourt, Rivers State, Nigeria \\ G. G. Kpee \\ Department of Educational Management, Faculty of Education, \\ University of Port Harcourt, Rivers State, Nigeria
}

\begin{abstract}
The design adopted for this study was correlation. Population of the study consisted of all the 504 public secondary schools principals in 18 LGAs in Cross Rivers State. However, purposive sampling technique was use to select the 504 principals a sample for the study. There were two research questions and two hypotheses formulated for the study. Questionnaire was the instrument used for data collection with 20 items and titled "Generation and Allocation of Internal Revenue for School Administration Questionnaire" (GAIRSAQ). The GAIRSAQ was validated by the researchers' supervisors as well as two experts from Measurement and Evaluation in the Department of Psychology, Guidance and Counseling. Split half statistic associated with Spearman Brown prophecy formula was used to estimate the reliability of the questionnaire with co-efficient of 0.86 . Mean, standard deviation and rank order were used to answer the research questions while z-test was used to test the hypotheses at 0.05 level of significance. The findings of the study showed that rentage, community assistance, PTA contributions, fund raising campaigns were among the strategies for generating revenue in public secondary schools in Cross River State. The study also showed that revenue was majorly allocated based on the urgency of the need and that revenues generated were utilized for different administrative needs such as provision of facilities, maintenance and day-to-day running of the school. Therefore, it was recommended among others that principals should develop an equitable revenue allocation formula for effective administration of public secondary schools in Cross River State.
\end{abstract}

Keywords: Generating, Allocating, Revenue, Public, Secondary Schools

\section{INTRODUCTION}

The education system in Nigeria consists of three basic levels namely; primary, secondary and tertiary. The secondary level of education serves as an intermediary between the primary and tertiary levels of education. Secondary education is the point where the output from the primary level of education are refined and prepared for tertiary education either in the University, Polytechnic or College of Education. Defining the importance of secondary education, Edet and Osika (2017:20) stated that "secondary education is critical to the development of the nation being the bridge between primary and tertiary education". This level of education serves as an input for tertiary education where the needed manpower for the different sectors of the economy is produced.

Secondary education occupies a prime position in the education system in Nigeria. Secondary education in Nigeria dates back to $6^{\text {th }}$ June, 1859 with the establishment of the Church Missionary Society Grammar school known as CMS Grammar school in Lagos (Ojo \& Olajide, 
2014). This period marked the emancipation of secondary education in Nigeria after almost 17years that Western Education was introduced in Nigeria in 1842. Missionaries have also contributed to educational development in the country by establishing different types of secondary schools with the intention of achieving their religious and social objectives which included the ability of beneficiaries to read, write and communicate. The principal body of most of these missionary bodies within and outside the country was however responsible for the administration of these schools. This marked the beginning of the expansion of secondary education in Nigeria.

Management of resources is one of the key functions of a principal as the administrative head of a school. Similarly, one of the basic resources that a school principal must learn to manage is the revenue generated internally in the school. One of the modalities used by principals for meeting the financial needs of secondary schools under their control is developing mechanism for generating revenue internally. This they do bearing in mind that the revenue they generate has direct impact on the welfare of teachers, students and other stakeholders connected to the school. It is therefore the responsibility of the principal to ensure that measures are developed internally to beef up available revenue which should be able to meet the expenditure of the school for optimum performance among teachers, students and the entire school system.

Due to high enrollment rate in public schools, principals are faced with very huge expenditure to meet the needs of the students and teachers. Therefore, in the absence of government support, principals of public schools have a responsibility to play in securing additional funds internally for meeting the expenditure of the school for a smooth school administration. According to Nwakpa (2016), secondary school principals these days depend on donations, the Parents Teachers Association (PTA), appeal fund and sales of school crafts among others as a way of generating revenue internally. This has helped to improve on the financial base of most public secondary schools.

\section{Statement of the Problem}

One of the problems confronting formal education is that of inadequate funding. Secondary schools are not left out of the problem of inadequate funding which has continued to affect the academic performance of students due to shortages in the in the acquisition of the right quality and quantity of human and material resources needed for meaningful teaching and learning.

Recently, the government has pointed out the need for private support in the funding of education in the country including secondary education. Principals of public secondary schools therefore have a lot of responsibilities on their shoulder to device other sources of generating revenue internally and allocate the available ones adequately for effective administration of their school. The problem this study therefore intends to solve is to find out the sources available internally for principals to generate revenue and allocate the revenue generated for the administration of the school were they head.

\section{Purpose of the Study}

The objectives of the study were to:

1. find out the sources used by principals for generating revenue internally for the administration of public secondary schools in Cross River State.

2. determine the strategies adopted by the principal for allocating revenue generated internally for the administration of public secondary schools in Cross River State.

\section{Research Questions}

The following research questions were answered in the study: 
1. What are the sources used by principals in generating revenue internally for the administration of public secondary schools in Cross River State?

2. What are the strategies adopted by the principal for allocating revenue generated internally for the administration of public secondary schools in Cross River State?

\section{Hypotheses}

The following hypotheses were tested at 0.05 level of significance:

1. There is no significant difference between the mean ratings of the opinions of male and female principals on the sources used by principals in generating revenue internally for the administration of public secondary schools in Cross River State.

2. There is no significant difference between the mean ratings of the opinions of male and female principals on the strategies adopted by the principal for allocating revenue generated internally for the administration of public secondary schools in Cross River State.

\section{LITERATURE REVIEW}

\section{Internally Generated Revenue and School Administration}

Revenue is a monetary concept that is usually used to refer to the money accruing to an individual or institution. Revenue can be generated from either the internal activities carried out by an entity of as a form of support from other external bodies. Nnanseh and Akpan (2013:165-166) stated that "internally generated revenue are those revenues that are derived within". This implies that these forms of revenue are generated from the internal business activities of the organization. Supporting this idea, Venture in Onuoha (2013:9) stated that "internally generated funds are those funds that are realized through the efforts or operations of an entity itself". This type of revenue is derived from the goods or services produced from the internal activities of an organization. This therefore implies that any formal organization that produces goods or services can generate revenue internally from these activities.

Administration is seen as the ability to administer or make available a resource that is needed for a task to be performed effectively. Ogbonnaya (2009) saw administration as the utilization of human, financial, and material resources in maximizing the realization of goals or objectives. The concept can therefore be better understood as the ability to make resources available for the achievement of desired goals and objectives.

\section{Sources for Generating Revenue Internally in Secondary Schools}

The importance of generating revenue internally for effective administration of secondary schools cannot be overemphasized. Therefore, principals must adopt the right strategies for generating revenue internally. Some of these strategies which have been adopted by secondary school principals for internal revenue generation includes but are not limited to the following:

Renting of School Facilities: The school is an educational institution established with the collection of so many physical facilities. These facilities include the library, classroom, sport facilities, office blocks among others. However, since the school has a specific time of operation within the week and during the day, the rest of the time when students and teachers are not in the school provides an opportunity for the school administrators to use these facilities for commercial purposes.

There are secondary schools were the school field is provided for public use for occasions such as weeding, birthday, naming etc. at an agreed fee. The school principal therefore has this privilege of using all the available physical facilities as a revenue earner for the administration of the school. Similarly, the school filed is also rented to other schools that have no provision 
for fields which can be used for annual inter-house sports. There are other facilities that can be rented by the school principal such as chairs, tables and other learning resources. These facilities can also be leased at an agreed rate and this will help to augment the finances available for the principals use.

Business Venture: One of the ways a principal can generate revenue for the administration of the school is by establishing business ventures within the school. There are schools that operate a mini-shop were consumables are sold. These shops provide opportunity for students, parents and the members of the public to buy consumables for personal use. There are business opportunities such as painting, weaving and other small scale businesses that can be operated by the schools and this provides an opportunity for the school to generate revenue internally.

Principals also generate revenue by running businesses that involves the provision of services. The principal with the cooperation of other staff of the school can provide commercial services to members of the public as well as those within the school at an agreed rate. When this is done over time, it can help the principal to generate additional revenue to whatever the principal has generated from other sources. The principal also has the capacity to partner with other commercial institutions that will help the school to make income from such business partnership for the administration of the school.

Fund Raising Campaign: Financial campaign involves the principal reaching out through the media and other public outlets to inform educational stakeholders of the financial needs of the school. Fund raising camping also involves gathering parents and other educational stakeholders from time to time to make financial commitment for meeting the needs of the school. The school authority could appeal in writing to wealthy persons in the community where the school is located for financial assistance in order to develop their school" (Nwakpa, 2016:12). This will help to increase the revenue of the school.

There are secondary schools that have fixed a particular day in the academic session as a day for fund raising for the school. These schools use this opportunity to invite parents and public personalities to make financial commitment for the administration of the school. Similarly, some of these schools also have financiers who support the school when there is a financial need and these individuals are sported out when school organize such fund raising campaign. This provides extra fund for the principal for school a administration.

Parent Teacher Association: It is part of the policy of some secondary schools that parents of students whether past or present are members of the Parents Teacher Association. The Parents Teachers Association aside from providing support for the school by constructing physical facilities for the use of all stakeholders. One of the alternative strategies is the involvement of Parents Teachers' Association (PTA) in its administration. PTA is one of the ways through which funds could be raised for secondary school administration (Edet \& Osika, 2017:21). Schools that do not have a Parents Teachers Association will not benefit from the financial support that can be gotten from parents for the administration of the school.

Alumni Association: Alumni should be taught, from day one, that their financial and moral contributions are important. They should be taught to be committed and enthusiastic long before they are ready to join the association (Olu, 2012:230). Schools that desire to improve on their internal revenue generation base need to establish a functional alumni association. The alumni help to bring past students of the school together who are doing well in the society. 
These individuals also play an important role in assisting the school financially for meeting the needs of the school.

There are various other strategies that are applied by school principals to boost the revenue base of their schools. Some of these strategies include community involvement, proceeds from school farm activities, and support from non-governmental organizations. These strategies have the capacity to increase the revenue available to the principal for meeting the administrative needs of the school.

\section{Strategies for Allocating Internally Generated Revenue in Secondary Schools}

Revenue allocation strategies that can be adopted by the principal include but is not limited to the following:

Student's Needs: The primary reason why most schools especially the public ones are in business are to provide education which is a social need to students. This means that if the students are not in school, the school will have no reason to be in existence. Therefore, attention is usually given to students as they form the basis for investment in the educational system (BenDavid-Hadar \& Ziderman, 2010). This forms the basis for allocation of revenue generated in the school

There are principals who allocate available revenue as long as it has to be for the satisfaction of the need of students. The students therefore stand at the center of all financial allocations in the school. The principal therefore gives priority during revenue allocation to expenditures that have to do with satisfying student's needs. Allocation of revenue in this case therefore focuses on providing educational resources and services for meeting the needs of students so that goals and objectives of education can be achieved.

Teacher's Needs: The Federal Republic of Nigeria (2013) has rightly pointed out in the National Policy on Education on the need to give attention to teacher education as a way of achieving the goals and objectives of education in the country. This is why educational scholars have pointed out that there is no nation that can rise above the quality of the teaching force. This is the reason why some principals do not joke with any expenditure that will improve on the quality of teachers.

The teacher is one of the important educational stakeholders in any educational system. The teacher needs to be motivated and trained. Similarly, there are other ways the teacher needs to be empowered to improve on their service delivery and this will require some financial obligations. Therefore, some principals have made it a point of duty to put teachers' needs at the center of their revenue allocation. This is because they believe that when the needs of the teachers are satisfied, it will be easier to meet the educational goals of school.

Population: One of the criteria used by the government for the allocation of revenue to the state government is the population of the state. This is because it is believed that needs are more essential when it affects a lot of people (Baker, Sciarra \& Farrie, 2010). This strategy has also been applied by some principals in the allocation of revenue in the school. The principal therefore allocate internally generated revenue for school expenditure if he or she believes that the need will satisfy the expectation of a more people in the school.

The principal who applies this strategy believes that revenue allocated will be justified if there are lots of people that will benefit from the expense made. The principal will therefore give priority to expenses that will touch more educational stakeholders such as parents, teachers 
and students before revenue can be allocated for such expense. The principal in this situation considers the crowd who will benefit from prospective expenditure before revenue can be allocated from the funds generated internally.

Educational Programmes: There are different educational programmes that are floated from time to time in school to meet the educational expectation of stakeholders. The principal who puts these criteria into consideration ensures that attention is given to educational programmes that will contribute to the achievement of the goals and objectives that the principal and the school wish to achieve.

There are different programmes that are being pursued in secondary schools across the country. Some of these programmes include entrepreneurial programmes, gender related programmes, peace building programmes etc. When a principal and other educational programmes have such a programme to pursue, the principal ensures that during allocation of revenue generated internally, more attention is giving to the educational programmes which the principal and the school as a whole are known to pursue.

Urgency of Need: The needs of the school are enormous. There are principals who think that revenue should be allocated first to needs that are very urgent before others can be considered. In this case, revenue generated internally must be allocated to needs that are very pressing so as to prefer further damages. For example, when there is a need that is a threat to life or a need that will stop educational activities from going on in the school, the principal need to allocate resources to these areas as this will affect the entire activities in the school. Allocation of fund is therefore based on the urgency of the need other than other criteria used in other public institutions.

There are other criteria that are used for the allocation of revenue by the principal. These revenue allocation strategies include rate of educational enrollment, the need for equality, internal revenue generation effort or contribution of the department or individual. There strategies are used by the principal to ensure that revenue generated internally in the school are strategically located for the best reasons where such funds can be said to have been properly utilized.

\section{METHODOLOGY}

Design used for the study was correlation. The population of the study was 504 public secondary schools principals in 18 LGAs in Cross Rivers State. Similarly, purposive sampling technique was use to select the 504 principals as sample for the study. Questionnaire was the instrument used for data collection with 20 items and titled "Generation and Allocation of Internal Revenue for School Administration Questionnaire" (GAIRSAQ). The questionnaire was validated by the researchers' supervisors as well as two experts from Measurement and Evaluation in the Department of Psychology, Guidance and Counseling. Split half statistic associated with Spearman Brown prophecy formula was used to estimate the reliability of the questionnaire with co-efficient of 0.86 . Mean, standard deviation and rank order were used to answer the research questions while z-test was used to test the hypotheses at 0.05 level of significance. 


\section{RESULTS}

Research Question One: What are the sources used by principals in generating revenue internally for the administration of public secondary schools in Cross River State?

Table 1: Mean and standard deviation scores of the sources used by principals in generating revenue internally for the administration of public secondary schools in Cross River State

\begin{tabular}{|c|c|c|c|c|c|c|c|c|c|}
\hline \multirow[t]{2}{*}{ S/No } & \multirow[t]{2}{*}{ ITEMS } & \multirow{2}{*}{\multicolumn{3}{|c|}{ Male Principal $n=307$}} & \multirow{2}{*}{\multicolumn{3}{|c|}{$\begin{array}{l}\text { Female Principal } n= \\
174\end{array}$}} & \multirow{2}{*}{$\begin{array}{c}\text { Av. } \\
\text { Mean }\end{array}$} & \multirow[t]{2}{*}{ Remark } \\
\hline & & Mean & & & & & Rank & & \\
\hline 1 & $\begin{array}{l}\text { Revenue is generated in the school by } \\
\text { selling produce from the farm }\end{array}$ & 2.37 & 0.83 & $10^{\text {th }}$ & 2.58 & 0.84 & $10^{\text {th }}$ & 2.48 & Disagreed \\
\hline 2 & $\begin{array}{l}\text { The alumni contribute to the revenue } \\
\text { generated internally in the school }\end{array}$ & 2.67 & 0.83 & $8^{\text {th }}$ & 2.96 & 0.80 & $7^{\text {th }}$ & 2.82 & Agreed \\
\hline 3 & $\begin{array}{l}\text { Fund raising campaigns are organized } \\
\text { by the school }\end{array}$ & 3.30 & 0.77 & $2^{\text {nd }}$ & 3.31 & 0.74 & $3^{\text {rd }}$ & 3.31 & Agreed \\
\hline 4 & $\begin{array}{l}\text { The Parents Teachers Association } \\
\text { (PTA) contributes to the internal } \\
\text { revenue of the school }\end{array}$ & 3.23 & 0.76 & $4^{\text {th }}$ & 3.05 & 0.76 & $5^{\text {th }}$ & 3.14 & Agreed \\
\hline 5 & $\begin{array}{l}\text { Facilities are sometimes rented to } \\
\text { generate revenue for the school }\end{array}$ & 3.17 & 0.72 & $5^{\text {th }}$ & 3.18 & 0.72 & $4^{\text {th }}$ & 3.18 & Agreed \\
\hline 6 & $\begin{array}{l}\text { The school has a kiosk that contributes } \\
\text { to the financial base of the school }\end{array}$ & 3.27 & 0.77 & $3^{\text {rd }}$ & 3.36 & 0.74 & $1^{\text {st }}$ & 3.32 & Agreed \\
\hline 7 & $\begin{array}{l}\text { The school community contributes to } \\
\text { the schools internal revenue }\end{array}$ & 2.97 & 0.76 & $6^{\text {th }}$ & 2.98 & 0.79 & $6^{\text {th }}$ & 2.98 & Agreed \\
\hline 8 & $\begin{array}{l}\text { There are non-governmental } \\
\text { organizations that contributes to the } \\
\text { revenue of the school }\end{array}$ & 3.37 & 0.69 & $1^{\text {st }}$ & 3.36 & 0.77 & $1^{\text {st }}$ & 3.37 & Agreed \\
\hline 9 & $\begin{array}{l}\text { Revenue is generated internally in the } \\
\text { school by engaging in competitions }\end{array}$ & 2.56 & 0.86 & $9^{\text {th }}$ & 2.75 & 0.85 & $9^{\text {th }}$ & 2.66 & Agreed \\
\hline 10 & $\begin{array}{l}\text { The school generates revenue from } \\
\text { students crafts }\end{array}$ & 2.70 & 0.68 & $7^{\text {th }}$ & 2.81 & 0.83 & $8^{\text {th }}$ & 2.76 & Agreed \\
\hline & Average Mean & 2.96 & 0.77 & & 3.03 & 0.78 & & 3.00 & Agreed \\
\hline
\end{tabular}

In table 1, all the items had mean scores above the criterion mean of 2.50 for both male and female principals except item one from the responses of the male principals. This indicated that all the principals agreed that all the items listed were strategies adopted by them to generate revenue internally for the administration of the school under their leadership. This fact is supported by the grand mean of 3.00 above the criterion mean. The low mean score of 2.37 suggested that the principals were of the opinion that selling of farm produce was not a common strategy adopted by them in generating revenue internally in public secondary schools in Cross River State. 
Research Question Two: What are the strategies adopted by the principal for allocating revenue generated internally for the administration of public secondary schools in Cross River State?

Table 2: Mean and standard deviation scores of the strategies adopted by the principal for allocating revenue generated internally for the administration of public secondary schools in Cross River State

\begin{tabular}{|c|c|c|c|c|c|c|c|c|c|}
\hline \multirow[t]{2}{*}{ S/No } & \multirow[t]{2}{*}{ ITEMS } & \multicolumn{3}{|c|}{ Male Principal n= 307} & \multicolumn{3}{|c|}{$\begin{array}{l}\text { Female Principal } n= \\
174\end{array}$} & \multirow{2}{*}{$\begin{array}{c}\text { Av. } \\
\text { Mean }\end{array}$} & \multirow[t]{2}{*}{ Remark } \\
\hline & & Mean & SD & Rank & Mean & SD & Rank & & \\
\hline 11 & $\begin{array}{l}\text { Revenue is allocated based on the } \\
\text { needs of students }\end{array}$ & 2.76 & 0.82 & $8^{\text {th }}$ & 2.87 & 0.82 & $6^{\text {th }}$ & 2.82 & Agreed \\
\hline 12 & $\begin{array}{l}\text { The teachers take a central stage in the } \\
\text { allocation of revenue in the school }\end{array}$ & 3.12 & 0.76 & $4^{\text {th }}$ & 3.20 & 0.75 & $3^{\text {rd }}$ & 3.16 & Agreed \\
\hline 13 & $\begin{array}{l}\text { New educational programmes are first } \\
\text { considered during revenue allocation }\end{array}$ & 3.04 & 0.75 & $5^{\text {th }}$ & 3.13 & 0.73 & $4^{\text {th }}$ & 3.09 & Agreed \\
\hline 14 & $\begin{array}{l}\text { Population of those in need of an } \\
\text { educational resource are considered } \\
\text { during revenue allocation }\end{array}$ & 3.28 & 0.71 & $2^{\text {nd }}$ & 3.07 & 0.79 & $5^{\text {th }}$ & 3.18 & Agreed \\
\hline 15 & $\begin{array}{l}\text { The urgency of a need takes priority } \\
\text { during revenue allocation in the school }\end{array}$ & 3.37 & 0.74 & $1^{\text {st }}$ & 3.27 & 0.76 & $1^{\text {st }}$ & 3.32 & Agreed \\
\hline 16 & $\begin{array}{l}\text { The level of students enrollment } \\
\text { determines the revenue allocated to a } \\
\text { need in the school }\end{array}$ & 2.99 & 0.79 & $6^{\text {th }}$ & 2.87 & 0.84 & $6^{\text {th }}$ & 2.93 & Agreed \\
\hline 17 & $\begin{array}{l}\text { The need for equality is the basis for } \\
\text { revenue allocation }\end{array}$ & 3.25 & 0.75 & $3^{\text {rd }}$ & 3.26 & 0.86 & $2^{\text {nd }}$ & 3.26 & Agreed \\
\hline 18 & $\begin{array}{l}\text { The revenue generated by a unit or } \\
\text { department determines the revenue } \\
\text { allocated to them }\end{array}$ & 2.98 & 0.84 & $7^{\text {th }}$ & 2.87 & 0.84 & $6^{\text {th }}$ & 2.93 & Agreed \\
\hline 19 & $\begin{array}{l}\text { Revenue is allocated based on } \\
\text { contribution to the goals and objectives } \\
\text { of education }\end{array}$ & 2.72 & 0.86 & $9^{\text {th }}$ & 2.80 & 0.86 & $9^{\text {th }}$ & 2.76 & Agreed \\
\hline 20 & $\begin{array}{l}\text { Principals allocate revenue based on } \\
\text { their personal belief }\end{array}$ & 2.59 & 0.83 & $10^{\text {th }}$ & 2.43 & 0.91 & $10^{\text {th }}$ & 2.51 & Agreed \\
\hline & Average Mean & 3.01 & 0.79 & & 2.98 & 0.82 & & 2.99 & Agreed \\
\hline
\end{tabular}

In table 2 all the items had mean scores above the criterion mean score of 2.50 for both male and female principals except item 20 from the responses of the female principals. This indicated that all the principals agreed that all the items listed are strategies adopted by them for allocating revenue generated internally for the administration of the school under their leadership. This fact is supported by the grand mean of 2.99 above the criterion mean. The low mean score of 2.43 suggested that the principals were of the opinion that revenue allocation according to the principals belief was not a common strategy adopted by them in allocating internally generated revenue in public secondary schools in Cross River State.

Hypothesis One: There is no significant difference between the mean ratings of the opinions of male and female principals on the sources used by principals in generating revenue internally for the administration of public secondary schools in Cross River State.

Table 3: z-test analysis of the difference between the mean ratings of the opinions of male and female principals on the sources used by principals in generating revenue internally for the administration of public secondary schools in Cross River State

\begin{tabular}{lcccccccc}
\hline \multicolumn{1}{c}{ Variable } & $\mathbf{n}$ & Mean & SD & df & z-cal. & z-crit. & $\begin{array}{c}\text { Level of } \\
\text { Significance }\end{array}$ & Decision \\
\hline Male Principals & 307 & 2.96 & 0.77 & 479 & 0.96 & 1.96 & 0.05 & $\begin{array}{c}\text { Failed to } \\
\text { reject }\end{array}$ \\
Female Principals & 174 & 3.03 & 0.78 & & & & & \\
\hline
\end{tabular}


In table 3, at 497 degrees of freedom and at 0.05 level of significance, the calculated z-value of 0.96 was by far less than the $\mathrm{z}$-critical value of \pm 1.96 . Furthermore, no significant difference existed between the mean scores of the male and female principals in their responses. Consequently, since at 497 degree of freedom and 0.05 level of significance, the calculated zvalue was less than the critical z-value and no significant difference existed between the mean ratings of the opinions of male and female principals on the strategies adopted by principals in generating revenue internally in public secondary schools in Cross River State

Hypothesis Two: There is no significant difference between the mean ratings of the opinions of male and female principals on the strategies adopted by the principal for allocating revenue generated internally for the administration of public secondary schools in Cross River State

Table 4: z-test analysis of the difference between the mean ratings of the opinions of male and female principals on the strategies adopted by the principal for allocating revenue generated internally for the administration of public secondary schools in Cross River State

\begin{tabular}{lcccccccc}
\hline \multicolumn{1}{c}{ Variable } & $\mathbf{n}$ & Mean & SD & df & z-cal. & z-crit. & $\begin{array}{c}\text { Level of } \\
\text { Significance }\end{array}$ & Decision \\
\hline Male Principals & 307 & 3.01 & 0.79 & 479 & 0.39 & 1.96 & 0.05 & $\begin{array}{c}\text { Failed to } \\
\text { reject }\end{array}$ \\
Female Principals & 174 & 2.98 & 0.82 & & & & & \\
\hline
\end{tabular}

In table 4, at 497 degrees of freedom and at 0.05 level of significance, the calculated z-value of 0.39 was by far less than the z-critical value of \pm 1.96 . Furthermore, no significant difference existed between the mean score of the male and female principals in their response. Consequently, since at 497 degree of freedom and 0.05 level of significance, the calculated zvalue was less than the critical z-value and no significant difference existed between the mean scores of the male and female principals in their responses, the researcher failed to reject the null hypothesis and established that no significant difference existed between mean ratings of the opinions of male and female principals on the strategies adopted by the principal for allocating revenue generated internally in public secondary schools in Cross River State

\section{DISCUSSION OF FINDINGS}

\section{Sources Used by Principals in Generating Revenue Internally for the Administration of Public Secondary Schools in Cross River State}

Generation of revenue internally at any level of education is an issue that is generating more attention among educational stakeholders in this era of economic recession. This is because the dwindling resources available to the government have made it difficult for the government alone to fund education even at the secondary level of education. This has made it mandatory for the government to request for private involvement in the funding of education in the country. Therefore, the principals as the administrative head of the school have a lot of expectations from him in this era.

The need for adequate funding of secondary education has placed on the principal the urgent need to diversify the generation of revenue internally in the school by applying the right strategies. Study carried out by Ekpoh and Okpa (2017) showed that most schools invest into consultancy services, commercialization of physical facilities as strategies for generating revenue internally. There are principals that have explored internal and external sources as a way of boosting revenue generated internally at the secondary level of education. This makes it possible for the principal to generate revenue that is needed for the administration of the school. 
Revenue experts have pointed out that generating revenue in any business venture requires the provision of services of manufacturing of products. This implies that in applying the right strategy for generating revenue internally for the administration of the school, the principal must consider manufacturing products or providing services which will help to expand the revenue stream of the school. The revenue generation strategy of the principal must therefore involve solving problems in the society through which revenue can be generated. This will help to provide a steady source of revenue for the administration of the school. Furthermore, the study conducted by Boma (2018) revealed that there are school principals who have established old students association in their schools and this has helped to provide steady revenue for the school. This strategy can also be adopted by schools in Cross River State. This agrees with the position of Nkwoh (2011) who revealed in the findings of his study that most principals lose huge revenue when they do not relate with their past students especially students from the immediate community where the school is located.

There are various service provision that some principals have adopted as a way of generating revenue internally for the administration of the school. Schools with robust farmland even go the extent of providing agricultural services and this agrees with the position of the study conducted by Amos and Koda (2018) who pointed out that providing poultry service is an important source of revenue generation to most secondary schools. The responses of the principals showed that principals provide quality educational services as a way of generating revenue from the beneficiaries of these services. This includes revenue generated from the PTA, alumni of the school, sales from school kiosk, renting of physical facilities and other members of the community who support the school financially and this serves as a revenue source in the school. This is in line with the position of the study conducted by Edet and Osika (2017) who pointed out that the PTA has proven to be a sustainable source of internal revenue in the administration of secondary education for so many years. Furthermore, the principals responded that they produce products such as handcrafts. However, it was disagreed that there are school farms from where the principals generate revenue. This implies that secondary schools in the state that does not have school farms are missing a lot financially from not having a school farm where farm produce can be produced and sold to support the school financially.

\section{Strategies Adopted by the Principal for Allocating Revenue Generated Internally for the Administration of Public Secondary Schools in Cross River State}

The way revenue generated from the school is allocated is equally as important as the revenue generated. This is because when the principal has been able to generate revenue internally, the failure to allocate the revenue appropriately will have a negative impact on the administration of the school. The principal therefore needs to adopt the best strategy for the allocation of revenue in the school. For example, the study conducted by Uko and Obeten (2018) pointed out that principals most times allocate funds to alleviate poverty among parents and this helps to ensure that students remain in school.

There are different stakeholders in the school whose interest must be protected in the school. This includes the student, teacher, government etc. The study carried out by Bua and Adzongo (2014) revealed that prompt payment of salaries from revenue generated internally contributes significantly to the management of secondary schools and this is an area that principals need to give adequate attention. Therefore, the principal as the administrative head of the school must be able to adopt the best strategy for allocating revenue generated internally so as to protect the interest of all stakeholders. The failure to do so will dampen the interest of these stakeholders and affect the actualization of the goals and objectives of education in the school. 
The responses from the male and female principal's sample for the study showed that principals allocate revenue based on all the important criteria itemized. The principals pointed out from their responses that revenue is sometimes allocated based on the need of the teachers and the students. On the part of Olaotun (2012), the student gets the highest share of revenue allocated to stakeholders in the school and this helps to promote students retention and performance. Similarly, revenue is allocated based on the urgency of a need and also based on the contribution of the need to the achievement of the goals and objectives of education.

The responses of the respondents also revealed that there are principals that allocate revenue based on their personal opinion of the relevance of the need. This may explain the reason why the outcome of the study carried out by Igbineweka and Enowoghomwenma (2017) showed that there is still a low positive relationship between internally generated revenue and secondary education in some states in Nigeria. However, this may not be in the best interest of the school as some of the principals can use this opportunity to enrich their own interest. It is therefore important for appropriate checks and balances to be put in place to ensure that principals do not use available revenue just the way they dim fit without making wider consultation with other educational stakeholders whose interests will also be affected by the way the revenue is generated and allocated in the school.

The allocation of revenue generated in the school for meeting the needs of the school is a task that should not be carried out by the principal alone. According to Arong and Ogbadu (2010) financial probity from the principal helps to improve the quality of education since quality education is one of the concern of the principal when expending revenue for school use. The revenue generated in the school should be allocated based on an agreed rule. This will help in the effective administration of the school. For example, Adan and Keiyoro (2017) revealed that when revenue generated is allocated to take care of teacher's needs, it makes it easy for the principal to win the support of the teachers for further revenue generation in the school. This implies that in the process of allocating funds from the revenue generated internally, all stakeholders should be represented and should be made to present their needs which will then be addressed based on an agreed strategy or formula.

The study concluded thus:

\section{CONCLUSION}

It was concluded that principals of public secondary schools in Cross Rivers State have variety of sources from where they generate revenue internally for the administration of the school that they head.

\section{RECOMMENDATIONS}

The following recommendations were made in line with the findings of the study:

1. There is need for public secondary school principals to liaise with educational stakeholders in their school on how to expand the sources from which revenue can be generated for the administration of the school either directly or indirectly from these stakeholders.

2. Principals of secondary schools also need for develop an all-encompassing formula for the allocation of revenue generated internally for meeting the needs of the school. This will help to avoid a situation where revenue is allocated to one need at the expense of the other. Therefore, developing a revenue allocation formula will help to ensure that all expenses are met for the effective administration of the school. 
Nyeh, C. O., \& Kpee, G. G. (2019). Generating and Allocating Internal Revenue for Public Secondary School Administration in Cross River State. Advances in Social Sciences Research Journal, 6(10) 249-260.

\section{References}

Adan, S. M. \& Keiyoro, P. (2017). Factors influencing the implementation of income generating projects in public secondary schools in Isiolo North County, Kenya: International Academic Journal of Information Sciences and Project Management, 2(1), 558-573

Amos, O. \& Koda, G. M. (2018). Contribution of school-based income generating activities in quality education provision in secondary schools managed by the Catholic Diocese of Moshi, Tanzania: British Journal of Education, $6(4), 49-69$

Arong, F. E. \& Ogbadu, M. A. (2010). Major causes of declining quality of education in Nigeria from administrative perspective: A case study of Dekina Local Government Area. Canadian Social Science, 6(3), 183-198

Baker, B. D., Sciarra, D. G. \& Farrie, D. (2010). Is school funding fair: A national report card. Retrieved from https://files.eric.ed.gov/fulltext/ED520522.pdf

BenDavid-Hadar, I. \& Ziderman, A. (2010). A new model for equitable and efficient resource allocation to schools: The Israeli case. Retrieved from https://www.econstor.eu/bitstream/10419/35983/1/621335118.pdf

Boma, P. B. (2018). Financial management and practices for principals on quality service delivery in secondary schools in Rivers State: International Journal of Innovative Finance and Economics Research, 6(2), 62-69

Bua, F. T. \& Adzongo, P. I. (2014). Impact of financial management on secondary school's administration in Zone A senatorial district of Benue State Nigeria: Public Policy and Administration Research, 4(9), 95-103

Edet, A. O. \& Ekpoh, U. I. (2017). Administrative challenges of academic heads of department in tertiary institutions in Cross River State: Mediterranean Journal of Social Sciences, 8(2), 129-135

Edet, A. O. \& Osika, E. O. (2017). Exploring alternative strategies of financing public secondary schools for sustainable development in Cross River State, Nigeria: Education for Today, 13(1), 20-26

Ekpoh, U. I. \& Okpa, O. E. (2017). Diversification of Sources of Funding University Education for Sustainability: Challenges and Strategies for Improvement: Journal of Education, Society and Behavioural Science, 21(2), 1-8

Federal Republic of Nigeria (2013). National policy on education. Yaba, Lagos: NERDC press

Igbineweka, V.O. \& Enowoghomwenma, D. E. (2017). Internally generated revenue (IGR) suitability and quality assurance in some Nigerian Universities: International Journal of Educational Benchmark, 7(2), 116-124

Nkwoh, K. (2011). Analysis of administrative roles of principals in private secondary schools in Aba education zone of Abia state: Journal of Educational Administration 2(1), 33-41

Nnanseh, M. \& Akpan, S. S. (2013). Internally generated revenue (IGR) and infrastructural development in Akwa Ibom State: European Journal of Business and Management, 5(31), 164-172

Nwakpa, P. (2016). Alternative sources of financing secondary education in Ebonyi State by the school administrators: British Journal of Education, 4(4), 10-14

Ogbonnaya, N. (2009) Education finance. Onitsha: Cape publishers International Limited

Ojo, O. E. \& Olajide, A. A. D. (2014). The Nigerian secondary school graduate and national development: A case of re-education of teachers. Research on Humanities and Social Sciences, 4(6), 21-24

Olatoun, A. A. (2012). Resource utilization and internal efficiency in Nigerian secondary schools: Implications for socio problems of education. International Journal of Sociology and Anthropology, 4(1), 23-30

Olu, S. A. (2012). Innovative strategies for financial management in Nigerian public secondary schools: US-China Education Review, 2, 224-235

Onuoha, L. N. (2013). Financing higher education in Nigeria: The role of internally generated revenues and how university managements can maximize the sources. Canadian Social Science, 9(1), 9-14

Uko, E. S. \& Obeten, O. O. (2018). Management of secondary school principals for poverty reduction in achievement of sustainable development goals in Cross River State, Nigeria: American Journal of Educational Research, 6(1), 65-69 